\title{
Kroniek: De g-grond, waar komen wij vandaan, waar zijn wij, waar gaan wij naartoe?
}

\author{
mr. Maarten van Kempen*
}

Op 1 juli 2015 veranderde het ontslagrecht door invoering van de Wet werk en zekerheid. De black box van de gewichtige reden van artikel 7:685 BW werd ingewisseld voor een semi-gesloten systeem van ontslaggronden met zo concreet mogelijke normen. Doelstelling hiervan was om juridisering van ontslag tegen te gaan en de rechtszekerheid voor werkgevers en werknemers zo veel mogelijk te bevorderen. ${ }^{1}$ Is dat gelukt? In deze bijdrage staat de g-grond, oftewel de verstoorde arbeidsverhouding, centraal.

\section{Inleiding}

Deze bijdrage analyseert de ontwikkeling van bijna vijf jaar literatuur en jurisprudentie met als doel te bezien hoe de rechtspraktijk is omgegaan met de verstoorde arbeidsverhouding als redelijke grond voor ontslag. Deze kroniek omvat de gepubliceerde rechtspraak en literatuur van 1 juli 2015 tot 1 april 2020. De rechtspraak is ontleend aan de database van rechtspraak.nl. ${ }^{2}$

\section{Waar komen wij vandaan, de situatie tot 1 juli 2015}

Tot 1 juli 2015 leek het leven in de arbeidsrechtpraktijk vrij overzichtelijk. Het ontslagrecht kende twee routes, elk met eigen criteria, rechtsgang en mechanisme voor het berekenen van de ontslagvergoeding. De route via het UWV kende een gesloten stelsel van ontslaggronden neergelegd in het Ontslagbesluit en de Beleidsregels Ontslagtaak UWV. Op basis hiervan kon de arbeids-

\footnotetext{
Maarten van Kempen is advocaat bij DVAN advocaten in Utrecht. De titel is geïnspireerd op het schilderij van Paul Gauguin ( $D^{\prime}$ ou Venons Nous / Que Sommes Nous / Où Allons Nous). Het hangt in het Museum of Fine Arts in Boston.

1. MvT, Algemeen deel (ontvangen 29 november 2013), Kamerstukken II 2013/14, 33818, nr. 3, p. 43-46

2. Met dank aan mr. Rachel D. Rietveld, manager ArbeidsmarktResearch UVA B.V. (magontslag.nl) en promovenda aan de UvA/TU Delft, voor het aanleveren van het rechtspraakoverzicht. Ook heel veel dank aan mr. Katerina Nikolaou, juridisch medewerker bij DVAN Advocaten voor haar hulp bij het bij het verzamelen en interpreteren van de data.
}

overeenkomst na verkrijging van de ontslagvergunning worden opgezegd. Eventuele ontslagvergoedingen moest een werknemer zelf bewerkstelligen door het starten van een procedure op grond van kennelijk onredelijk ontslag op grond van artikel 7:681 BW. De tweede route betrof de ontbindingsprocedure via de kantonrechter op grond van artikel 7:685 BW. Dit betrof een open systeem waarbij de kantonrechter slechts hoefde vast te stellen of sprake was van een gewichtige reden die ontslag rechtvaardigde. De kantonrechter kon daarbij naar eigen inzicht een billijke vergoeding toekennen. Hoger beroep was niet mogelijk. De open norm van artikel 7:685 BW gaf de rechter een grote mate van vrijheid om te bepalen of sprake was van een situatie die een gewichtige reden opleverde. Wel werden drie hoofdcategorieën onderscheiden te weten (1) disfunctioneren, (2) verstoorde verhoudingen of wegvallen van vertrouwen en (3) bedrijfseconomische of bedrijfsorganisatorische redenen. Kruit constateerde in zijn proefschrift dat het aantal ontbindingsverzoeken ex artikel 7:685 $\mathrm{BW}$ in verband met verstoorde arbeidsrelaties tussen de $60 \%$ en $65 \%$ bedroeg van het totaal aantal ontbindingszaken. ${ }^{3}$ In de categorie verstoorde arbeidsrelaties vielen de ontbindingen waarbij de werkgever en de werknemer vanwege hun onderlinge verstandhouding geen heil meer zagen in voortzetting van het dienstverband. De ontbindingspraktijk wist zich in de loop der jaren te ontwikkelen tot een robuust en snel werkend systeem van ontslagrecht, onder meer doordat de kantonrechters gebruikmakten van een min of meer gestandaardiseerde vorm van berekening van de ontslagvergoeding door middel van de kantonrechtersformule.

Vergelijkend onderzoek naar de mate van het gebruik van de twee ontslagroutes in het kader van de grondslag verstoorde verhoudingen is mij niet bekend. Het is echter mijn ervaring dat de UWV-route in dergelijke gevallen nauwelijks werd bewandeld. Dat blijkt ook uit het staatje 'Ontslagvergunningsprocedure naar reden' opgenomen in de jaarlijkse Statistiek Ontbindingsvergoedingen van het tijdschrift Arbeidsrecht in de jaren voor de inwerkingtreding van de Wet werk en zekerheid (Wwz). De UWV-route was duidelijk voorbehouden aan de gronden bedrijfseconomische grondslag en langdurige arbeidsongeschiktheid, die door de jaren heen

3. P. Kruit, De ontbindingsbeschikking ex art. 7:685 BW getoetst, Den Haag: Bju 2012 
goed waren voor $90-95 \%$ van het aantal ontslagvergunningsaanvragen. ${ }^{4}$ Deze twee gronden zijn thans neergelegd in de a- en de b-grond en ook als zodanig nu primair het terrein van het UWV, terwijl de persoonsgerichte gronden, waaronder de verstoorde arbeidsverhouding, het exclusieve domein zijn geworden van de rechter.

\section{Waar zijn wij, de situatie sinds 1 juli 2015}

De wetgever heeft met de $\mathrm{Wwz}$ de open norm van artikel 7:685 BW en het gesloten stelsel van ontslaggronden zoals neergelegd in BBA 1945 min of meer bij elkaar gepakt en vervolgens geopteerd voor de redelijke ontslaggrond waarbij herplaatsing niet mogelijk is. De arbeidsrechtelijke ontbindingspraktijk is verder ook niet meer het exclusieve domein van de kantonrechter omdat hoger beroep mogelijk is. Het begrip 'redelijke ontslaggrond' lijkt op het eerste gezicht een open norm, maar is het niet omdat het nader is uitgewerkt in een gesloten stelsel van ontslaggronden neergelegd in artikel 7:669 lid 3 sub a-i BW. ${ }^{5}$ Bij het formuleren van die ontslaggronden heeft de wetgever aansluiting gezocht bij de regels zoals die voor de inwerkingtreding van de $\mathrm{Wwz}_{\mathrm{w}}$ waren opgenomen in het Ontslagbesluit en in de daarop gebaseerde Beleidsregels Ontslagtaak UWV. Het systeem van de Wwz brengt wel mee dat een ontslaggrond voldragen moet zijn wil sprake zijn van een redelijke ontslaggrond. Een combinatie van onvoldragen ontslaggronden was tot 1 januari 2020 niet mogelijk. Dat geldt dus ook voor de g-grond die ziet op de verstoorde arbeidsverhouding.

In de literatuur heeft de g-grond de nodige aandacht gekregen. Zo zijn er uitgebreide toelichtingen in de bekende wettenbundels en arbeidsrechtelijke handboeken. Verder verwijs ik hierbij graag naar de bijdragen van Peters uit 2017 in AR Updates ${ }^{6}$ en, meer recent, Buijs in de bundel Deining, opgedragen aan Sjef de Laat in het kader van zijn afscheid als kantonrechter te Utrecht. ${ }^{7}$ Uitgebreid onderzoek is er van de hand van Mutlu, die concludeert dat er veel verschillende situaties zijn die onder het bereik van de g-grond vallen. ${ }^{8}$

4. Zie bijvoorbeeld C.J. Loonstra en P. Kruit, 'Statistiek ontbindingsvergoedingen 2005: een jaar van stabiliteit', Arbeidsrecht 2006/36 en P. Kruit, 'Statistiek Ontbindingsvergoedingen 2013: het einde van de ontbindingsvergoeding aangekondigd', Arbeidsrecht 2014/43.

5. De i-grond is pas toegevoegd met ingang van 1 januari 2020

6. S.S.M. Peters, 'G-grond gegrond? De verstoorde arbeidsverhouding als ventiel van het nieuwe ontslagrecht', AR Updates 14 juni 2017.

7. D.J. Buijs, 'De verstoorde arbeidsrelatie - een van oudsher ongrijpbaar begrip', in Deining (in balie, rechtspraak en academie), opstellen aangeboden aan mr. dr. J.J.M. (Sjef) de Laat, (red. Leopold Holtus) Den Haag: Sdu Uitgevers 2019, p. 166.

8. C. Mutlu, 'Driehonderd keer ontslag wegens verstoorde arbeidsverhouding', TAP 2019/113.
Ook het kwantitatieve onderzoek ${ }^{9}$ van Houweling, Kruit en Kersten naar de ontbindingspraktijk 2015-2018 mag uiteraard niet onvermeld blijven. Uit dit kwantitatieve onderzoek komt naar voren dat de g-grond verreweg de meest voorkomende ontslaggrond is omdat deze vaak ook als alternatief voor de d-grond en e-grond fungeert. De g-grond fungeert daarmee als een soort 'restgrond' voor afgewezen d- en e-grond-verzoeken. Daar komt volgens de onderzoekers bij dat deze grond ook de grootste kans op succes biedt, met ongeveer een fifty/ fifty verhouding tussen toe- en afwijzing. Ik merk op dat Kruit en Kersten in een recent onderzoek tot de conclusie komen dat sprake is van een tendens dat kantonrechters nog sneller dan voorheen bereid zijn te ontbinden op basis van de g-grond. Voor het jaar 2018 berekenden Kruit en Kersten dat 57\% leidde tot toewijzing op basis van de g-grond en in 2019 zelfs $76 \%$ ! $^{10}$ Kruit en Kersten verklaren deze stijgende tendens door de uitspraak van de Hoge Raad van 16 februari 2018, ${ }^{11}$ waarin expliciet is aangegeven dat de vraag wie van de verstoring van de arbeidsrelatie een verwijt kan worden gemaakt niet van belang is bij de beoordeling van de voldragen g-grond.

\subsection{Kwantitatieve analyse}

Het beroemde adagium 'There are three kinds of lies: lies, damned lies, and statistics' indachtig, ontkom ik niet aan het delen van enkele kwantitatieve gegevens. Het rechtspraakoverzicht omvat 929 werkgeversverzoeken (art. 7:671b BW) in eerste instantie (kantonrechter) waarbij onder meer een beroep is gedaan op de g-grond. Verder zijn er 245 uitspraken in tweede instantie (gerechtshoven).

Kijkend naar de uitspraken in eerste instantie (kantonrechter) zien we dat een aanzienlijk deel (763 gevallen) een combinatie van gronden betreft. De d-grond (190 gevallen), e-grond (578) en h-grond (238) komen in $80 \%$ van het totaal aantal verzoeken voor. ${ }^{12}$ Het gaat hier dus ook om verzoekschriften waar met name primair een beroep wordt gedaan op de d-grond of de e-grond. Het aantal ontbindingsverzoeken van werkgeverskant waarin louter en alleen een beroep is gedaan op de g-grond bedraagt $166(17,4 \%)$. De overige gronden ( $\mathrm{a}, \mathrm{b}$, c en $\mathrm{f}$ ) komen in combinatie met de g-grond dus nauwelijks voor. Bij de combinatieverzoeken met de d-, e- en/of h-grond zien we dat het percentage toewijzingen op de oorspronkelijke grond (d, e of h) rond de $30 \%$ ligt. Die percentages komen ook overeen met die uit de

9. A.R. Houweling, P. Kruit en I.H. Kersten, 'Evaluatieonderzoek ontbindingspraktijk Wwz 2015-2018. Van een vast "muizengaatje" naar een nog vaster "konijnenhol"', TAP 2018/266.

10. P. Kruit en I.H. Kersten, 'Statistiek Ontbindingsprocedure 2018-2019: De Wwz werkt toch! Of toch niet...', Arbeidsrecht 2020/16.

11. HR 16 februari 2018, ECLI:NL:HR:2018:220

12. Opgeteld kom je uit op meer gevallen, maar dat wordt verklaard doordat deze gronden ook gecombineerd voorkomen (bijvoorbeeld de e- en de h-grond). 
onderzoeken van Houweling, Kruit en Kersten. ${ }^{13}$ Het aantal uitspraken waarin daadwerkelijk inhoudelijk over de g-grond is beslist, bedraagt 706. Van die 706 uitspraken zijn 290 verzoeken (41,1\%) afgewezen en 356 $(50,4 \%)$ toegewezen. Voor het overige betreft het uitspraken waarop niet inhoudelijk is beslist. Het percentage toewijzingen $(50 \%)$ sluit op zich aan bij de uitkomsten van het kwantitatieve onderzoek van Houweling, Kruit en Kersten over de periode tot en met 2018. Wat echter opvalt, is dat van die toewijzingen in 112 uitspraken (31\% van het aantal toewijzingen) feitelijk niet inhoudelijk op tegenspraak is beslist omdat de kantonrechter constateerde dat partijen het erover eens waren dat sprake was van verstoorde verhoudingen. De vraag is dan ook of het percentage toewijzingen realiter niet lager dan 50\% zou moeten zijn en het aantal afwijzingen dus hoger als met name de werknemer een andere proceshouding zou hebben ingenomen en zich op het standpunt zou hebben gesteld dat geen sprake was van verstoorde verhoudingen. Interessant is verder dat het aantal verzoekschriften waarin alleen op basis van de g-grond is geprocedeerd (166 uitspraken) tot een groot aantal toewijzingen (123) leidt (74\%). Het aantal afwijzingen bij de combinatiegronden ligt dan ook hoger dan het algemene afwijzingspercentage, namelijk rond de $45 \%$. Dit zijn dus de verzoeken die zowel op basis van de oorspronkelijke d-, e- of h-grond zijn afgewezen alsook op de g-grond.

Een kwantitatieve analyse van de uitspraken van de hoven leidt niet tot bijzondere inzichten. Van de 245 uitspraken in hoger beroep betreft het 103 gevallen waar de kantonrechter de arbeidsovereenkomst oorspronkelijk had ontbonden op basis van de g-grond. De overgrote meerderheid van de uitspraken van de kantonrechter blijft gewoon in stand. In een enkel geval wordt wat gesleuteld aan de hoogte van de billijke vergoeding.

\subsection{De verstoorde arbeidsverhouding in het} systeem van de $\mathrm{Wwz}$

Als we kijken naar de wettekst rijst de vraag wat een verstoorde arbeidsverhouding nu eigenlijk precies inhoudt. De term is immers als juridisch begrip opgenomen in de wet. Het BBA 1945 kende een ruime definitie van het begrip arbeidsverhouding: de verhouding tussen werkgever en werknemer in de zin van artikel 7:610 BW (degene die in dienst van een ander arbeid verricht) alsmede de rechtsbetrekking tussen iemand die persoonlijk arbeid verricht voor een ander en degene voor wie hij deze arbeid verricht. $\mathrm{Nu}$ is dit begrip als zodanig opgenomen in het arbeidsovereenkomstenrecht, terwijl volgens de definitie in het BBA 1945 die arbeidsverhouding gewoon de arbeidsovereenkomst zelf is. Juridisch gaat het dus om een verstoring van de rechtsbetrekking.

13. A.R. Houweling, P. Kruit en I.H. Kersten, 'Evaluatieonderzoek ontbindingspraktijk Wwz 2015-2018. Van een vast "muizengaatje" naar een nog vaster "konijnenhol"', TAP 2018/266. en P. Kruit en I.H. Kersten, 'Statistiek Ontbindingsprocedure 2018-2019: De Wwz werkt toch! Of toch niet...', Arbeidsrecht 2020/16. Bij ons wijkt de h-grond wel wat af. Dat kan te maken hebben met het feit dat specifiek is gezocht naar uitspraken in combinatie met de g-grond.
Het begrip verstoorde arbeidsverhouding ziet dus niet op feitelijke verstoorde verhoudingen tussen mensen. Als je echter kijkt naar de ontbindingspraktijk van voor 1 juli 2015, dan is dat wel wat men daar onder verstond.

Die verhoudingen tussen mensen zijn mijns inziens ook allesbepalend bij de g-grond. Om te beginnen is het begrip werkgever een abstract juridisch begrip, een van de partijen bij de arbeidsovereenkomst, het rechtssubject. Wat een werkgever dan precies omvat, zegt de wet niet. De Wet op de Ondernemingsraden definieert het begrip onderneming als elk in de maatschappij als zelfstandige eenheid optredend organisatorisch verband waarin krachtens arbeidsovereenkomst of krachtens publiekrechtelijke aanstelling arbeid wordt verricht. Vanuit de organisatieleer zou je kunnen zeggen dat het staat voor een wijze van samenwerken tussen mensen om een gezamenlijk doel te bereiken. Die samenwerking is noodzakelijk om dat doel te bereiken. De kwaliteit van die samenwerking hangt af van de invulling door individuen en van de verwachtingen die men van die samenwerking heeft. Men verwacht een bepaalde bijdrage aan de hand van de competenties en vaardigheden die het individu geacht wordt te hebben, men verwacht een bepaald sociaal gedrag en men verwacht dat iedereen is gecommitteerd aan het gezamenlijke doel. Bij de beoordeling of sprake is van een verstoorde arbeidsverhouding gaat het eigenlijk altijd over een beoordeling van de intermenselijke relatie. Het conflict, de vertrouwensbreuk, ontstaat tussen mensen. Het zijn de mensen die met elkaar samenwerken. In dat kader is vermeldenswaardig dat de Nederlandse Vereniging voor Arbeidsen Bedrijfsgeneeskunde (NVAB) in juli 2019 met een richtlijn rondom conflicthantering is gekomen. Deze richtlijn heeft inmiddels de status van professionele standaard voor bedrijfsartsen. In de richtlijn wordt de volgende definitie van een conflict gehanteerd:

'Twee individuen, één individu en een groep of twee groepen, binnen de grenzen van een arbeidsorganisatie, hebben een arbeidsconflict als tenminste één van de partijen vindt dat de andere partij haar dwarsboomt of ergert. ${ }^{14}$

Het ervaren van een conflict of vertrouwensbreuk is in die zin dus een volstrekt subjectief gegeven en hoeft beslist niet wederzijds te zijn. De rechtbank Oost-Brabant verwoordde dit al vrij snel na inwerkingtreding van de Wwz als volgt: ${ }^{15}$

'Een arbeidsrelatie kan verstoord raken indien een werkgever geen vertrouwen meer heeft in haar werknemer en herstel van de verstoring in haar ogen is uitgesloten. Deze vertrouwensbreuk hoeft niet wederkerig te zijn.'

14. Zie NVAB-richtlijn. Deze definitie was trouwens al geformuleerd in de STECR-richtlijn 2014.

15. Rb. Oost-Brabant 15 oktober 2015, ECLI:NL:RBOBR:2015:7909. 
Het gaat echter niet alleen om de vraag of sprake is van verstoorde verhoudingen, maar of deze zodanig zijn dat van de werkgever redelijkerwijze niet kan worden verwacht de arbeidsovereenkomst te laten voortduren. De Wwz heeft niet de subjectieve ervaring als uitgangspunt genomen, maar bevat juist vanuit het oogpunt van werknemersbescherming een grondenstelsel met objectiveerbare normen. Bij de a-grond liggen die bijvoorbeeld vast in de Ontslagregeling, de b-grond kent een kader van medische en arbeidsdeskundige normen, bij de d-grond is dat aan de hand van een functieomschrijving en een verbetertraject, bij de e-grond is dat neergelegd in het kenbaarheidsvereiste. Bij de g-grond is die objectiveringsmethodiek er echter niet. De wettekst spreekt alleen maar van de vraag of van de werkgever redelijkermijze gevergd kan worden de arbeidsovereenkomst te laten voortduren. De rechter heeft dus geen objectief toetsingskader voorhanden, behoudens de vraag of herstel van verhoudingen mogelijk is. Dat verklaart ook dat er zo veel verschillende situaties onder het bereik van de g-grond kunnen vallen. Het kan daarbij uitmaken of sprake is van een grote of kleine organisatie, ${ }^{16}$ ook in verband met mogelijke herplaatsing. Het kan uitmaken of sprake is van een geschil op de werkvloer met veel collega's of in de top van de organisatie waar het onderlinge vertrouwen binnen een klein gremium van MT-leden en toezichthouders onder druk kan komen. ${ }^{17}$ Hier komt ook de vraag aan de orde welke rol de werkgever heeft gehad bij het ontstaan van het conflict en wat de werkgever eraan heeft gedaan om de verstoringen op te heffen of tot beheersbare proporties terug te brengen.

\subsection{De g van gedrag?}

In het kader van deze kroniek probeer ik toch een aantal categorieën van oorzaken te benoemen die in de feitencomplexen van de ruim 1100 uitspraken van kantonrechter en gerechtshoven aan de orde komen. De meest verstrekkende conclusie is dat het eigenlijk zonder uitzondering gaat om kwesties waarin persoonlijke verhoudingen een rol spelen die de samenwerking negatief beïnvloeden. Een grove indeling zou de volgende kunnen zijn:

1. onoplosbare problemen met de persoon van de werknemer;

2. gebrek aan vertrouwen op basis van houding en functioneren;

3. verlies van vertrouwen door verwijtbare gedragingen van de werknemer;

4. wederzijds wantrouwen als gevolg van escalatie van een van bovengenoemde categorieën.

De toetsing en motivering zal per hoofdcategorie kunnen verschillen. Zo kan bij de eerste categorie worden gekeken in hoeverre die problemen met de persoon volledig toerekenbaar zijn aan de werknemer. Het verwachtingspatroon speelt hier een rol. Zo oordeelde de kantonrechter Alkmaar bijvoorbeeld dat een werkgever als het werkvoorzieningschap meer dient te dulden van haar werknemers die met beperkingen kampen (het betrof hier een SW-medewerker) dan een reguliere werkgever. ${ }^{18} \mathrm{Bij}$ categorieën 2 en 3 schurkt het feitencomplex sterk aan tegen de criteria van de d- en de e-grond. De vraag is dan of een onvoldragen d- of e-grond als zodanig toch kan leiden tot verstoorde verhoudingen of dat daarvoor extra feiten en omstandigheden noodzakelijk zijn. De data laten zien dat kantonrechters kritisch zijn. Dat is ook wel verklaarbaar vanuit de gedachte dat niet zozeer de wijze van samenwerken het probleem is, maar bijvoorbeeld de functionele invulling. De sleutel tot herstel van het succes van de samenwerking ligt dan bijvoorbeeld in het functionele verbetertraject.

Als de rechter vaststelt dat sprake is van wederzijds wantrouwen dan is de ontbinding op de g-grond gegeven. De vaststelling dat sprake is van wederzijds wantrouwen wil overigens niet zeggen dat partijen het hierover eens zijn. Juist bij tegenspraak, in de regel van de werknemer die, al dan niet strategisch, stelt dat terugkeer beslist mogelijk is, pakt de rechter als 'buitenstaander' de rol van observator, waarbij uitingen van een werknemer richting leidinggevende als 'joker' en 'sukkel ${ }^{19}$ het de rechter op zich ook niet altijd moeilijk hoeven te maken. Dit is dan toch het terrein van de ervaringsdeskundige kantonrechters die veel zaken en conflicten voorbij zien komen. We zien dat terug in hun uitspraken met zinnen als: 'de wijze waarop partijen hun tegengestelde standpunten jegens elkaar hebben geformuleerd" ${ }^{20}$ of 'partijen maken daarvoor elkaar reeds langere tijd over en weer te veel verwijten ${ }^{21}$ waardoor de rechter tot de slotsom komt dat sprake is van verstoorde verhoudingen zodanig dat van werkgever niet gevergd kan worden de arbeidsovereenkomst in stand te houden. De rechtspraak neigt er thans steeds meer naar om rechters te rouleren. Ervaren kantonrechters worden dan vervangen door 'vers bloed' uit de civiele sector of de strafsector. Enerzijds leidt dat natuurlijk tot verversing en dus vernieuwing van inzichten, anderzijds lijkt juist die ervaringsdeskundigheid van kantonrechters van belang, zeker waar het gaat om het herkennen van verstoorde arbeidsrelaties.

De volgende feitencomplexen kwamen in de afgelopen vijf jaar regelmatig aan de orde:

1. discussies over functioneren en gedrag op het werk (combinatie d/g-grond);

2. verlies van vertrouwen door verwijtbaar gedrag van de werknemer (combinatie e/g-grond);

3. ziekte- en re-integratieperikelen;
16. Over problemen in kleine organisaties zie bijvoorbeeld Hof Den Haag 23 augustus 2016, ECLI:NL:GHDHA:2016:2441; Hof Arnhem-Leeuwarden 15 november 2016, ECLI:NL:GHARL:2016:9099.

17. Zie bijvoorbeeld Hof Den Bosch 16 maart 2017, ECLI:NL:GHSHE: 2017:1027.
18. Rb. Noord-Holland 27 oktober 2015, ECLI:NL:RBNHO:2015:9756.

19. Rb. Zeeland-West-Brabant 26 april 2016, ECLI:NL:RBZWB:2016:5381.

20. Rb. Noord-Holland 17 mei 2016, ECLI:NL:RBNHO:2016:4052.

21. Rb. Amsterdam 9 november 2016, ECLI:NL:RBAMS:2016:8448. 
4. verlies van vertrouwen op managementniveau (combinatie h/g-grond);

5. onderlinge spanningen op de werkvloer.

- Discussies over functioneren en gedrag op het werk Veel zaken betroffen werkgeversverzoeken waarbij sprake was een feitencomplex waarin het functioneren of het gedrag van de werknemer binnen de organisatie aan de orde was. De verwijten raken aan het functioneren of de opstelling van de werknemer, maar leveren op dat moment geen d- of e-grond op. Het gaat dan om verwijten als: de onderlinge samenwerking verloopt moeizaam, gebrek aan collegialiteit en een weinig klantgerichte houding, ${ }^{22}$ de gespannen werkverhouding die door de naaste collega's van de werkgever in de samenwerking met werkneemster wordt ervaren, het - na daarop te zijn aangesproken - ontbreken van onderkenning daarvan door werkneemster en haar eigen rol daarin en het ontbreken van bereidheid haar houding te verbeteren, onvoldoende zelfreflectie, ${ }^{23}$ of 'drammerig' en ongewenst gedrag. ${ }^{24}$ Een gedraging die regelmatig voorkomt, is die van de werknemer die het gezag van de werkgever niet erkent, zoals het van meet af aan bagatelliseren door werknemer van geuite kritiek op het functioneren en het niet op waarde schatten van de continu door of namens werkgever gepleegde inspanningen gericht op het verbeteren van het functioneren van werknemer, ${ }^{25}$ de werknemer die publiekelijk laat weten dat zijn leidinggevende niet de competentie heeft om hem te beoordelen, ${ }^{26}$ of bij een eigengereide wijze van optreden van werknemer die werkgever niet langer behoefde te accepteren. ${ }^{27}$ Disfunctioneren (d-grond) levert dit in de regel niet op vanwege verzachtende factoren, zoals bijvoorbeeld een lang dienst verband ${ }^{28}$ of gebrek aan verbetertrajecten. De g-grond biedt hier wel soelaas, vaak vanwege de opstelling van de werknemer. Het is het gedrag van de werknemer dat in die gevallen kennelijk niet meer bijgestuurd kan worden.

- Verlies van vertroumen door vermijtbaar gedrag van de merknemer

In de vorige editie van $T v O$ verscheen al de kroniek over de e-grond. Uit die kroniek werd duidelijk dat de nadruk die de wetgever heeft gelegd op de kenbaarheid van het gedrag dat een werkgever wel of niet toelaatbaar acht, ook in de praktijk een belangrijke rol speelt. Als het gewenste en ongewenste gedrag niet door de werkgever in een duidelijke regel is vervat, is belangrijk dat een werkgever de werknemer van tevoren heeft gewaarschuwd (tenzij sprake is van een evidente ontoelaatbaarheid), zodat op die manier voor werknemer kenbaar is

22. Hof Arnhem-Leeuwarden 4 april 2016, ECLI:NL:GHARL:2016:2655

23. Hof Arnhem-Leeuwarden 18 oktober 2016, ECLI:NL:GHARL:2016: 8339.

24. Rb. Amsterdam 10 maart 2017, ECLI:NL:RBAMS:2017:1599.

25. Hof Arnhem-Leeuwarden 9 december 2016, ECLI:NL:GHARL:2016: 9998.

26. Hof Arnhem-Leeuwarden 17 januari 2017, ECLI:NL:GHARL:2017:601

27. Hof Amsterdam 18 mei 2019, ECLI:NL:GHAMS:2019:1922.

28. Rb. Limburg 20 juni 2018, ECLI:NL:RBLIM:2018:5873. dat zijn of haar gedrag niet toelaatbaar is. ${ }^{29}$ Een duidelijk geobjectiveerde grond, maar voor werkgevers vaak wel een nauw korset. Uit de kwantitatieve gegevens bleek al dat de g-grond zeer veel in combinatie met een ontslag op staande voet en de e-grond wordt gebruikt. Maar liefst in 578 verzoekschriften in eerste instantie is de e-grond opgevoerd en meende de werkgever de werknemer dus het een en ander te verwijten te hebben. In 174 van die zaken werd de e-grond gepasseerd, maar wees de kantonrechter het verzoek toch toe op basis van de g-grond. Zo is bijvoorbeeld naar het oordeel van de kantonrechter het belang van werkgever evident dat het personeel op tijd aanwezig is op de werkplek. Geoordeeld wordt dat de diverse incidenten (te laat komen, omgevallen rolstoel, klacht van klant over te hard rijden) geen redelijke grond voor ontbinding opleveren, zoals bedoeld in artikel 7:669 lid 3 sub e BW. De feiten en omstandigheden zijn daarvoor niet zwaarwegend genoeg. Vervolgens oordeelt de kantonrechter dat het aan werkneemster is te wijten dat zich een reeks incidenten heeft voorgedaan, het ene ernstiger dan het andere, welke incidenten tezamen, en in aanmerking genomen de vele gesprekken en waarschuwingen, uiteindelijk hebben geleid tot een verstoorde arbeidsverhouding. ${ }^{30}$ Of bedreigingen op het werk zoals: 'Als die de volgende week nog eens zo doet, sla ik al haar tanden uit haar bek', halen het niet op de e-grond, maar vervolgens wel op de g-grond. ${ }^{31}$ Gepleegde strafbare feiten in de privésfeer leiden ook tot uitwijken van de enaar de g-grond. Zo oordeelde de kantonrechter dat van werkgever in beginsel, gelet op haar bijzondere positie en de aard van haar bedrijfsvoering, niet verlangd hoeft te worden een voor drugsbezit veroordeelde werknemer in dienst te houden. Beëindiging op basis van de e-grond is echter te vergaand omdat het strafbare gedragingen in de privésfeer betrof. Mede gelet op de aard van het werk, de hoge integriteitseisen en het strenge antidrugsbeleid is ontbinding op de g-grond wel gerechtvaardigd. ${ }^{32}$ Ook de jurist van DAS rechtsbijstand die in strijd met zijn arbeidsovereenkomst voor eigen rekening een cliënt adviseerde, viel vanwege verzachtende omstandigheden niet onder de e-grond maar wel onder de g-grond. ${ }^{33}$ Er zijn ook uitspraken waarin de rechter niet echt een hard oordeel wil vellen en in het midden laat of de handelwijze van werknemer in juridische zin valt te kwalificeren als verwijtbaar handelen/ nalaten in de zin van artikel 7:669 lid 3 sub e BW, omdat duidelijk is dat werknemer door zijn handelwijze het in hem door de werkgever gestelde vertrouwen heeft beschaamd. ${ }^{34}$ Van dit soort uitspraken zijn er vele. Het klinkt allemaal wat minder hard in de uitspraak, maar het resultaat is hetzelfde, namelijk ontslag op basis van gedragingen die de werknemer min of meer toegere-

29. Michelle Kind en Maarten Stekelenburg, 'Kroniek e-grond: van onwil tot ontslag, wat mag?', TvO 2020/2.

30. Rb. Noord-Holland 20 januari 2016, ECLI:NL:RBNHO:2016:368.

31. Rb. Limburg 4 juli 2017, ECLI:NL:RBLIM:2017:6350.

32. Rb. Rotterdam 9 januari 2018, ECLI:NL:RBROT:2018:454.

33. Rb. Noord-Nederland 13 april 2016, ECLI:NL:RBNNE:2016:5846.

34. Rb. Noord-Nederland 31 mei 2017, ECLI:NL:RBNNE:2017:1968. 
kend/verweten worden, maar die kennelijk de toets van de e-grond niet doorstaan. Ook bij de gerechtshoven zien we regelmatig terugkomen dat de verstoorde verhoudingen hun grondslag vinden in aan de werknemer te verwijten gedrag, maar dat dat gedrag op zich niet zodanig verwijtbaar is dat is voldaan aan de e-grond. Zo oordeelde hof Amsterdam (Woondroomzorg) ${ }^{35}$ bijvoorbeeld in een zaak waar min of meer sprake was van 'de druppel die de emmer deed overlopen', dat de kantonrechter ten onrechte de ontbinding had geweigerd. Het hof stelde vast dat de werkneemster in kwestie veelvuldig in strijd met de afspraken handelde, achtte dit echter niet verwijtbaar in het kader van de e-grond, maar wel voldoende voor het aannemen van de g-grond. Dit oordeel achtte A-G De Bock in cassatie vervolgens niet onbegrijpelijk ${ }^{36}$ en zij stuitte een klacht hierover bij de Hoge Raad uiteindelijk ook af (art. 81 Wet RO). De vraag is dan of de g-grond niet verwordt tot een e-grond light. Op basis van bovengenoemde motiveringen ben $\mathrm{ik}$ wel geneigd die conclusie te trekken. De vraag is overigens of dat erg is. De verweten gedraging kan op zich voldoende zijn om het vertrouwen in een persoon te verliezen, ook al past deze niet in het 'korset' van de e-grond. De vraag die we onszelf zouden mogen stellen is of het korset van de e-grond wellicht wat minder strak zou moeten worden. De consequentie van verwijtbaar handelen voor de werknemer is immers dezelfde als bij een verstoorde arbeidsverhouding, namelijk ontslag, tenzij sprake is van ernstig verwijtbaar handelen.

\section{- Ziekte- en re-integratieperikelen}

In de rechtspraak zijn ook de nodige discussies geweest over het al dan niet nakomen van de re-integratieverplichtingen van de werknemer op grond van artikel 7:660a BW. Artikel 7:671b lid $5 \mathrm{BW}$ voorziet in bijzondere voorwaarden om bij niet-nakoming daarvan op basis van de e-grond te ontbinden. Zo moet de werknemer eerst worden gemaand tot nakoming en bij het ontbindingsverzoek moet een deskundigenverklaring worden overgelegd. In een situatie waarin de werkgever niet had voldaan aan bovengenoemde voorwaarden volgde toch ontbinding maar dan op basis van de g-grond. ${ }^{37}$ De mate waarin aan die re-integratieverplichting wordt voldaan, kan ertoe leiden dat ontbinding niet op de e-grond ${ }^{38}$ of zelfs artikel 7:686 $\mathrm{BW},{ }^{39}$ maar wel op de g-grond wordt gehonoreerd. Discussies over wel of niet arbeidsongeschikt leiden vaak tot oplopende conflicten en, veelal na mediation, tot ontbinding op grond van verstoorde verhoudingen. Het gaat hier om gevallen waarin werknemers zich verschuilen, maar ook om werkgevers die te hard duwen op het re-integratieproces. In bijna alle gevallen waarin ziekte en re-integratie aan de orde was, is ook een mediationproces doorlopen. Ik concludeer daaruit dat mediation een belangrijke rol

35. Hof Amsterdam 23 januari 2018, ECLI:NL:GHAMS:2018:251.

36. Conclusie A-G 9 februari 2019, ECLI:NL:PHR:2018:1484.

37. Zie bijvoorbeeld Rb. Noord-Nederland 13 oktober 2016, ECLI:NL: RBNNE:2016:5437.

38. Hof Den Haag 31 oktober 2017, ECLI:NL:GHDHA:2017:3074.

39. Hof Den Haag 11 juni 2019, ECLI:NL:GHDHA:2019:1502. is gaan spelen in het benaderen van arbeidsconflicten en dat het mislukken daarvan een belangrijke aanwijzing vormt dat is voldaan aan de criteria van de g-grond.

\section{- $\quad$ Verlies van vertroumen op managementniveau}

Op directieniveau speelt het onderlinge vertrouwen en de onderlinge samenwerking een belangrijke rol. Het gaat in de regel om een relatief kleine groep individuen die intensief samenwerken, waarbij de succesfactor van de werkgever zelf aan de orde is. Gebrek aan draagvlak zowel vanuit de aandeelhouder ${ }^{40} / \mathrm{RvT} / \mathrm{maatschap}^{41}$ als vanuit de werkorganisatie ${ }^{42}$ kan tot gedwongen vertrek leiden, ook al was er objectief op het functioneren wellicht niet zoveel aan te merken. Dit vertrouwen is essentieel, omdat een directeur een belangrijke spilfunctie $^{43}$ binnen de organisatie bekleedt. De rechtbank Noord Holland ${ }^{44}$ verwoordde dit als volgt:

'In de functie van [verweerster] als directeur is het noodzakelijk dat $z i j$ in voldoende mate het vertrouwen heeft van de RvT, haar mede-directeuren, het MT en de STM-hoofden, en dat zij met de betrokken leden daarvan in voldoende mate kan samenwerken. Zonder dat vertrouwen kan [verweerster] als directeur niet (meer) functioneren en is sprake van een verstoring van de arbeidsverhouding.'

De koppeling tussen gebrek aan vertrouwen en verstoorde verhoudingen is op zich niet onlogisch daar waar het gaat om de onderlinge samenwerking op die niveaus. Dat leidt overigens bij een voldragen g-grond maar in een enkel geval tot toekenning van een billijke vergoeding. Het merendeel van deze uitspraken leidt niet tot ernstig verwijtbaar handelen van de kant van de werkgever.

\section{- Onderlinge spanningen op de merkvloer}

Conflicten tussen collega's kunnen beslist aanleiding zijn om over te gaan tot ontslag op basis van de g-grond. De werkgever zal juist in dit soort kwesties niet alleen veel inspanningen moeten leveren om de spanningen op de werkvloer op te lossen, ${ }^{45}$ al dan niet via mediation of het aanspreken van de betrokkenen op het gedrag dat tot die spanningen aanleiding geeft. Doet een werkgever dat niet dan kan dat weer leiden tot de vaststelling dat sprake is ernstig verwijtbaar handelen van de werkgever $^{46}$ of tot afwijzing van het verzoek. In sommige gevallen is duidelijk een schuldige aan te wijzen, dan is het aanspreken op gedrag relatief eenvoudig. Als dat dan niet gebeurt, kan zich dat ook weer tegen de werkgever keren. Zo oordeelde de Rotterdamse kantonrechter dat sprake was van verstoorde verhoudingen omdat collega's

40. Hof Den Bosch 16 maart 2017, ECLI:NL:GHSHE:2017:1027

41. Hof Den Bosch 23 november 2017, ECLI:NL:GHSHE:2017:5114.

42. Hof Arnhem-Leeuwarden 31 maart 2017, ECLI:NL:GHARL:2017:2800.

43. Rb. Noord-Holland 23 mei 2018, ECLI:NL:RBNHO:2018:4410.

44. Rb. Noord-Holland 6 september 2019, ECLI:NL:RBNHO:2019:7944

45. Zie bijvoorbeeld Hof Den Bosch 11 april 2019, ECLI:NL:GHSHE: 2019:1355.

46. Rb. Midden-Nederland 12 januari 20126, ECLI:NL:RBMNE:2016:986; Rb. Rotterdam 5 november 2019, ECLI:NL:RBROT:2019:8666. 
niet meer met de werknemer door één deur konden, maar leverde dit ook ernstig verwijtbaar handelen van de werkgever op omdat die niets aan het gedrag van de betreffende werknemer had gedaan. ${ }^{47}$ In andere gevallen kan ook de rol van werknemers bij mogelijk herstel tot ontslag leiden bij onvoldoende medewerking. ${ }^{48}$

\subsection{Afwijzen of billijke vergoeding?}

Dit onderwerp was voorafgaand aan de inwerkingtreding van de $\mathrm{Wwz}$ een heet hangijzer. Het verlaten van het systeem van open normen met een grote bewegingsvrijheid voor de kantonrechter naar wat Duk noemde 'de rechter als bureaucraat' ${ }^{\text {'9 }}$ makte dat men vreesde dat de rechter zou worden geconfronteerd met kwesties die onder het oude regime van artikel 7:685 BW beslist tot ontbinding zouden leiden, met verdiscontering van mogelijke imperfecties in de vergoeding, maar die onder de $\mathrm{W}_{w z}$ de rechter voor een dilemma zouden kunnen stellen. Afwijzen, of toch maar ontbinden met toekenning van een billijke vergoeding? Sagel meende in zijn oratie ${ }^{50}$ bijvoorbeeld dat vanwege de tekst van de wet er niet veel ruimte zou zijn om te ontbinden als de verstoorde verhoudingen door de werkgever zijn veroorzaakt. Swelheim ${ }^{51}$ reageerde hierop door te stellen dat het de voorkeur zou hebben om bijvoorbeeld bij een imperfecte d-grond toch te ontbinden met toekenning van een billijke vergoeding. Peters onderkent dat de formulering van de g-grond ongelukkig is omdat is aangesloten bij wat redelijkerwijze van de werkgever gevergd kan worden, terwijl de wetgever heeft bedoeld aan te sluiten bij het criterium 'ernstig en duurzaam verstoord' zoals ook in het Ontslagbesluit destijds was geformuleerd. Zij beschouwt de g-grond als het ventiel dat het nieuwe ontslagrecht met zijn rigide systeem van ontslaggronden nodig heeft. ${ }^{52}$

Mijn indruk is dat de rechter niet schroomt om verzoeken af te wijzen. Uit de data bleek al dat ruim $40 \%$ van de verzoeken op basis van de g-grond wordt afgewezen. Bij toepassing van de combinatiegronden is dat percentage zelfs $45 \%$. Bij de afwijzingen zien we in de rechtspraak eigenlijk drie hoofdcategorieën:

1. werkgever heeft te weinig gesteld over de g-grond;

2. werkgever is veroorzaker van de verstoorde verhoudingen;

3. werkgever heeft te weinig gedaan om het conflict op te lossen.
- Werkgever heeft te meinig gesteld over de g-grond

Dit raakt aan het reguliere procesrecht dat ook op de ontbindingsprocedure van toepassing is. De werkgever zal feiten en omstandigheden moeten stellen en zo nodig bewijzen die tot de conclusie leiden dat sprake is van een verstoring van verhoudingen zodanig dat van de werkgever niet gevergd kan worden de arbeidsovereenkomst voort te zetten. Veel afwijzende beschikkingen hebben als motivatie dat het beroep op de g-grond onvoldoende is onderbouwd, ${ }^{53}$ of dat bij de g-grond slechts is verwezen naar dezelfde feiten en omstandigheden, die aan de andere ontslaggrond ten grondslag zijn gelegd. ${ }^{54}$ Een derde variant die regelmatig terugkeert, is dat het enkele feit dat niet is voldaan aan de andere grond, meebrengt dat ook het beroep op de g-grond niet kan slagen. ${ }^{55} \mathrm{Al}$ met al formuleerde de kantonrechter Leiden ${ }^{56}$ het recentelijk mijns inziens op juiste wijze:

'Vooropgesteld wordt dat een onvoldragen andere grond niet licht een grond voor verstoring van de arbeidsverhouding zal opleveren. Ook voor de g-grond geldt dat deze gestoeld moet zijn op een daartoe voldoende reden gevend feitencomplex en dat ook deze ontbindingsgrond separaat moet worden gemotiveerd.'

De kantonrechter Nijmegen wees hierbij ook op het gevaar dat als op grond van hetzelfde feitencomplex, dat voor de e-grond is gewogen maar te licht is bevonden, direct kwalificaties als 'onhoudbaar' en 'onwerkbaar' worden toegevoegd zonder bijkomende feiten en omstandigheden, de g-grond de omleidingsroute dreigt te worden voor de zwaarst denkbare sanctie die niet past in het strafregime van de cao. Dergelijke bijkomende feiten en omstandigheden zouden kunnen blijken uit een problematisch geworden werksfeer die belastend is voor de onderlinge verhoudingen en de voortgang van het werk. ${ }^{57}$

Buijs constateerde dit ook:

'Juist bij een verstoorde arbeidsrelatie is concretisering van de bron van de verstoring in de vorm van

53. Zie bijvoorbeeld Rb. Noord-Nederland 16 september 2015 ECLI:NL:RBNNE:2015:4245; Rb. Rotterdam 30 september 2015, ECLI:NL:RBROT:2015:7045, AR 2015-1841; Rb. Midden-Nederland 1 februari 2016 ECLI:NL:RBMNE:2016:715; Rb. Den Haag 21 juli 2016, ECLI:NL:RBDHA:2016:8375; Rb. Amsterdam 2 augustus 2016, ECLI:NL:RBAMS:2016:5655; Rb. Midden-Nederland 19 januari 2017, ECLI:NL:RBMNE:2017:144.

54. Zie bijvoorbeeld Rb. Noord-Nederland 16 september 2015 , ECLI:NL:RBNHO:2015:7893; Rb. Noord-Nederland 9 februari 2016, ECLI:NL:RBNNE:2016:458; Rb. Noord-Holland 10 februari 2016, ECLI:NL:RBNHO:2016:898; Rb. Noord-Nederland 22 februari 2016, ECLI:NL:RBNNE:2016:677; Rb. Limburg 30 maart 2016, ECLI:NL: RBLIM:2016:2770; Rb. Den Haag 9 juni 2017, ECLI:NL:RBDHA: 2017:6223

55. Zie bijvoorbeeld Rb. Midden-Nederland 22 november 2016, ECLI:NL:RBMNE:2016:6275.

56. Rb. Den Haag 9 januari 2020, ECLI:NL:RBDHA:2020:15. Zie Ktr. Rotterdam 30 maart 2020, ECLI:NL:RBROT:2020:2915, die aangeeft dat de g-grond niet is bedoeld als reparatie van een van de in art. 7:669 lid 3 BW genoemde gronden.

57. Rb. Gelderland 3 januari 2020, ECLI:NL:RBGEL:2020:85. 
feiten en omstandigheden geboden. Dat de helft van de ontbindingen op de g-grond worden afgewezen, kan niet alleen wijzen op een strakkere toepassing door rechters van de regels, maar ook daarop dat werkgevers (advocaten) nog niet of onvoldoende beseffen dat toewijzing van een ontbindingsverzoek van de werkgever staat en valt bij het stellen van feiten en omstandigheden. ${ }^{58}$

\section{- $\quad$ De merkgever is veroorzaker van de verstoorde verhoudingen}

In de beginjaren zijn er nog wel wat uitspraken geweest waarin het ontbindingsverzoek werd afgewezen omdat de verstoring van de arbeidsrelatie aan de werkgever te wijten was. ${ }^{59}$ Dit kwam voort uit de vraag of en in hoeverre een werkgever zou mogen 'profiteren' van een zelf gecreëerde verstoring in de arbeidsrelatie. Ook in de wetgeschiedenis is hieraan aandacht besteed en aangegeven dat zich dit kan vertalen in een oordeel dat sprake is van ernstig verwijtbaar handelen van de werkgever en dus een billijke vergoeding verschuldigd is. Hiervan uitgezonderd is de situatie dat de werkgever een verstoring van de arbeidsverhouding heeft gecreëerd met het enkele doel om een ontbinding van de arbeidsovereenkomst te forceren. Dergelijk gedrag zou volgens Verhulp niet 'beloond' mogen worden door toewijzing van het ontbindingsverzoek op de g-grond. ${ }^{60}$ De Hoge Raad heeft in $2018^{61}$ geoordeeld dat ontbinding op de g-grond ook mogelijk is als het ontstaan daarvan aan de werkgever te wijten is. Van belang is dat mogelijk (ernstig) verwijtbaar handelen van de kant van de werkgever op zichzelf geen reden is om een verzoek tot ontbinding van de arbeidsovereenkomst af te wijzen. De Hoge Raad laat echter ook doorschemeren dat bij de beoordeling of van de werkgever redelijkerwijze gevergd kan worden de arbeidsovereenkomst te laten voortduren van belang kan zijn dat een doelbemuste poging om de arbeidsverhoudingen te verstoren zou moeten leiden tot het oordeel dat wél van de werkgever kan worden gevergd de arbeidsovereenkomst voort te zetten.

Kruit geeft in zijn meest recente onderzoek aan dat er een tendens is dat het aantal toewijzingen met een billijke vergoeding toeneemt ten opzichte van het aantal afwijzingen en verklaart dat aan de hand van de uitspraak van de Hoge Raad. De vraag is of die toename berust op toeval of dat sprake is van een kentering in de wijze waarop de kantonrechter kijkt naar de situatie tussen partijen. Ik vraag mij af of sprake is van een kentering. Probleem blijft mijns inziens dat volgens de wet-

58. D. J. Buijs, 'De verstoorde arbeidsrelatie - een van oudsher ongrijpbaar begrip', in: Deining (in balie, rechtspraak en academie), opstellen aangeboden aan mr. dr. J.J.M. (Sjef) de Laat, (red. Leopold Holtus), Den Haag: Sdu Uitgevers 2019, p. 166.

59. Zie bijvoorbeeld Rb. Noord-Nederland 24 september 2015, ECLI:NL:RBNNE:2015:4508; Rb. Midden-Nederland 5 oktober 2015, ECLI:NL:RBMNE:2015:7666; Rb. Limburg 3 mei 2016 ECLI:NL:RBLIM: 2016:3816; Rb. Gelderland 20 juli 2016, ECLI:NL:RBGEL:2016:5506; Rb. Limburg 9 oktober 2017, ECLI:NL:RBLIM:2017:9772.

60. T\&C art. 7:669 lid 3 sub 9 BW

61. HR 16 februari 2018, ECLI:NL:HR:2018:220. tekst uitgangspunt is dat van de werkgever niet gevergd kan worden de arbeidsovereenkomst te laten voortduren. In gevallen waarin de werkgever als hoofdverantwoordelijke voor dit relatiedrama wordt gezien, ligt het meer voor de hand de vraag te stellen in hoeverre van de werknemer verwacht kan worden dat hij zich het gedrag van de werkgever laat welgevallen. Die mogelijkheid kent de g-grond echter niet en dit kan dus eigenlijk pas worden beoordeeld als ook de werknemer een eigen verzoek tot ontbinding indient. Deze procedurele verkokering makt dat rechters nog wel eens het laatste zien maar tot het eerste besluiten, met bijbehorende doelredenering dat van de werkgever niet kan worden verwacht de arbeidsovereenkomst in stand te houden. In hoger beroep heeft de rechter meer vrijheid op dat punt. Zo bepaalt artikel 7:682 lid $1 \mathrm{sub}$ b BW dat het hof de arbeidsovereenkomst kan herstellen, of een billijke vergoeding kan toekennen als herstel in redelijkheid niet mogelijk is, ongeacht de vraag van wie dat herstel dan redelijkerwijze niet gevergd kan worden. Peters ${ }^{62}$ bepleitte dan ook een wijziging van de formulering van de g-grond waarin niet aangehaakt hoeft te worden bij wat redelijkerwijze van de werkgever kan worden gevergd, maar wat redelijkerwijze mogelijk is. Dit onderwerp verdient wat mij betreft wat meer onderzoek en uitwerking, maar dat gaat het bestek van deze kroniek te buiten.

\section{- Werkgever heeft te meinig gedaan om het conflict op te lossen}

In veel uitspraken wordt stilgestaan bij de inspanningsverplichting van de werkgever. Die inspanningsverplichting lijkt vooral te worden gekoppeld aan discussies over disfunctioneren en verwijtbaar handelen, zeker als de daaraan gekoppelde $\mathrm{d}$ - of e-grond niet als voldragen wordt beschouwd. Hoewel uit ons kwantitatieve onderzoek is gebleken dat bij veel toegewezen ontbindingsverzoeken is verwezen naar de inspanningen van de werkgever via mediation en een mislukte mediation in de regel een toewijzing op basis van de g-grond oplevert, ${ }^{63}$ levert onwil van de werkgever of het doelbewust aansturen op beëindiging nog in de regel een afwijzing op. Bijvoorbeeld als duidelijk is dat de werkgever de mediation niet serieus neemt. Zo oordeelde de kantonrechter Zwolle ${ }^{64}$ bijvoorbeeld dat het enkele feit dat partijen tweemaal een mediationtraject hebben doorlopen, op zichzelf beschouwd nog niet meebrengt dat sprake is van een ernstige en duurzame verstoring van de arbeidsverhouding. Immers, ten tijde van het tweede traject heeft de werkgever al in de beginfase uitgesproken dat verdere samenwerking niet meer mogelijk is, zodat van een mediationtraject dat van zijn kant is gericht op her-

62. S.S.M. Peters, 'G-grond gegrond? De verstoorde arbeidsverhouding als ventiel van het nieuwe ontslagrecht' AR Updates 14 juni 2017.

63. Zie bijvoorbeeld Hof Arnhem-Leeuwarden 19 augustus 2016, ECLI:NL:GHARL:2016:6882; Hof Arnhem-Leeuwarden 8 februari 2017, ECLI:NL:GHARL:2017:923; Hof Den Bosch 9 maart 2017, ECLI:NL: GHSHE:2017:958;, Hof Den Bosch 24 augustus 2017, ECLI:NL:GHSHE: 2017:3683.

64. Rb. Overijssel 18 juli 2016, ECLI:NL:RBOVE:2016:2972. 
stel van de arbeidsverhouding niet kan worden gesproken.

\section{Waar gaan wij naartoe?}

Wat is een werkgever eigenlijk? Dat is natuurlijk een rechtssubject dat een contract aangaat met een werknemer. Meer niet. De werkgever vertegenwoordigt echter een samenwerkingsverband tussen mensen met een gemeenschappelijk doel. De aard van die samenwerking is bijzonder vanwege de gezagsverhouding en het loon dat daar tegenover staat. Het beëindigen van die samenwerking kan in het belang zijn van het samenwerkingsverband. Met instandhouding wordt het doel niet of minder snel bereikt. In die zin heiligt het doel de middelen. De rechtsbescherming van het individu, de werknemer, staat daar tegenover en dat vergt een objectief beoordelingskader om tot beëindiging over te gaan, de zogenoemde redelijke ontslaggrond. Voorafgaand aan de inwerkingtreding van de $\mathrm{W} w \mathrm{z}$ was het de vraag of de vervanging van de open norm van artikel 7:685 BW door het gesloten grondensysteem tot een vorm van verstarring zou leiden. De vraag was ook of de g-grond hierbij niet als veiligheidsventiel zou gaan functioneren, al dan niet in combinatie met de billijke vergoeding waardoor toch min of meer het oude vertrouwde systeem in stand zou blijven. Het is mijn conclusie dat dat niet het geval is. Van belang lijkt mij te onderkennen dat de g-grond uitgaat van onherstelbare deficiënties in de intermenselijke samenwerking die het belang van de organisatie (kunnen) schaden. Juist daar vindt ook de belangenafweging plaats of van de werkgever redelijkerwijze kan worden gevergd de arbeidsrelatie voort te zetten. In die zin is de g-grond een echte op zichzelf staande grondslag, zij het zonder duidelijk objectief beoordelingskader. Dat nodigt werkgevers en hun juristen dus uit tot pogingen om onvoldragen ontslaggronden via de g-grond te repareren. De dynamiek van de zitting en mogelijke schikking met behulp van de toepassing van de billijke vergoeding maken die verleiding ook groot. Rechters hebben zich echter geconformeerd aan het nieuwe systeem. Om recht te doen aan de g-grond wenst de rechter in staat te worden gesteld om de (on)mogelijkheden van de continuering van de arbeidsrelatie te beoordelen. Dat staat of valt met de wijze waarop werkgevers de feiten en omstandigheden in het ontbindingsverzoek formuleren. Omdat een objectief toetsingskader ontbreekt, ligt het voor de hand om, zoals bij de d-grond een disfunctioneringstraject als eis is gesteld, in ieder geval van verzoekende werkgevers te verlangen de feitelijke verstoorde verhouding te beschrijven, de consequenties daarvan voor de bedrijfsvoering en samenwerking, de belangenafweging tussen het bedrijfsbelang en het individuele belang, en in het kader van die belangenafweging inzichtelijk te maken wat de werkgever heeft gedaan om aan dat individuele belang van de werknemer tegemoet te komen. Vijf jaar rechtspraak leert dat de g-grond (te) veel is ingezet als restgrond om een eenzijdig ontslag te bewerkstelligen als alternatief voor met name de d-grond, de e-grond en de h-grond. Het leidt dan ook tot veel afwijzingen. De proceshouding van partijen bepaalt vaak of wel of niet ontbonden wordt. Actief onderzoek van rechters ter zitting leidt meer dan eens tot een gezamenlijke conclusie van partijen, zodat geen uitspraak op tegenspraak meer nodig is over de vraag of aan de criteria van de g-grond is voldaan. Werknemers die echt een afwijzing willen bewerkstelligen zullen zich dan ook enigszins bescheiden moeten opstellen in de procedure. Een te agressieve houding leidt anders tot de conclusie dat voortzetting van de arbeidsrelatie niet mogelijk is. De toekomst zal leren of rechters bij de beoordeling vaker de billijke vergoeding zullen inzetten en daarmee de ventielfunctie zullen vergroten of dat men bij de feiten blijft en dus komt tot afwijzing en wellicht doorpakt naar de i-grond. ${ }^{65}$ Werkgevers en hun juristen doen er dan ook goed aan die g-grond niet slechts als een restgrond in het verzoekschrift op te nemen, maar er echt werk van maken met bijbehorende feiten en omstandigheden waaruit die verstoring blijkt. Dat scheelt in de toekomst beslist een hoop afwijzingen.

65. Op het moment van het afsluiten van deze tekst lijkt van dat laatste overigens nog geen sprake. Tot 6 juli 2020 was er nog geen ontbindingsverzoek op basis van i-grond toegewezen. Zie hierover $\mathrm{O}$. van der Kind in de eerste analyse in AR Updates van 20 mei 202, 'De cumulatiegrond: combineren is nog niet zo eenvoudig'. 